\title{
Components of Procurement Reforms That Influence Expenditure Management in Secondary Schools in Kenya: A Focus on Tender Advertising
}

\author{
Eric Kibinu Kinuthia ${ }^{1}$, Paul A. Odundo ${ }^{2} \&$ Grace Nyagah $^{3}$ \\ ${ }^{1}$ Doctorate Candidate, Department of Education Administration, University of Nairobi, Kenya \\ ${ }^{2}$ Associate Professor, Department of Education Communication \& Technology, University of Nairobi, Kenya \\ ${ }^{3}$ Senior Lecturer, Department of Education Administration, University of Nairobi, Kenya \\ Correspondence: Paul A. Odundo, Associate Professor, Department of Education Communication \& Technology, \\ University of Nairobi, Jordan. E-mail: odundopaul@yahoo.com
}

Received: October 1, 2018

Accepted: November 20, 2018

Online Published: November 30, 2018

doi:10.5539/ijbm.v14n1p1

URL: https://doi.org/10.5539/ijbm.v14n1p1

\begin{abstract}
In Kenya, the public procurement sector has developed over the past 5 decades, from a system with no regulations to a system regulated by circulars; and currently, to a system firmly grounded on sound laws and policies. The aim of this study was to establish the extent to which public secondary schools in Nairobi City County had complied with relevant legislative and policy provisions guiding procurement reforms, as well as the effect of selected of reforms on expenditure management. This article focuses on the frequency of tender advertising. The evaluation research model III was applied to guide the research process and primary data were sourced in 2015 from 35 public secondary schools. Quantitative analysis included cross-tabulation with analysis of variance, chi-square statistic, correlation coefficient, as well as multiple regression. The study found that two-thirds of the schools were consistently advertising tenders as required by the legislative and policy provisions. Besides, the frequency of tender advertising significantly correlated with variation in procurement expenditure; and further caused a significant reduction in the same (beta weight $=-0.335$, $t$-statistic $=-2.639$ \& $\rho$-value $=0.014$ ), which signifies a positive influence on expenditure management. Ensuring consistency in advertising tenders is likely to help many schools improve on expenditure management; thereby, enhance the contribution of public procurement to national development.
\end{abstract}

Keywords: public procurement, reforms, expenditure management, tender advertising, secondary school

\section{Introduction}

Public procurement is the process of acquiring goods, services, and works by public sector institutions using public resources. It also entails the disposal of public assets. Public procurement plays an important role in national socio-economic development by supporting public institutions to deliver quality social services to citizens as well as stimulating growth in the commercial and manufacturing sectors (Lindskog, Brege \& Brehmer, 2006). Through public procurement, up to $60 \%$ of government revenue is injected into the economy, which in turn, stimulates private sector growth, creates employment opportunities and improves income (Organisation for Economic Cooperation and Development [OECD], 2001). In developing countries, the value of public procurement expenditure ranges between $9 \%$ and $13 \%$ of national Gross Domestic Products (GDP), while in developed nations, the value of procurement expenditure varies between $5 \%$ and $8 \%$ of the national GDP. In Kenya, the value of public procurement accounts for about $10 \%$ of the GDP, making it a large market for private sector, albeit with high opportunities for corruption (Kavula, Kalai \& Migosi, 2014; Kenya Anti-Corruption Commission [KACC] \& Public Procurement Oversight Authority [PPOA], 2009).

Sound procurement practices are essential for public procurement to make meaningful contribution to national development (KIPPRA, 2006; Odhiambo \& Kamau, 2003; World Bank, 2002). Whereas sound practices reduce expenditure and enhance efficiency, unsound practices often culminate to wastage of public resources, which in turn, deprives citizens of quality social services and thwarts growth in the commercial and manufacturing sectors. The basic principles of sound procurement practice include accountability, where effective mechanisms are established to enable governments spend resources carefully, knowing clearly that they are accountable to 
members of the public; efficiency, which requires that procurement processes be carried out as cost effectively as possible; as well as competitiveness, which requires procurement to be carried out by competition unless there are convincing reasons for single-sourcing. Additional principles of sound procurement practice include transparency, effectiveness, consistency, fair dealing, as well as responsiveness to aspirations, expectations and needs of target societies (OECD, 2009; World Bank, 2002; Thai, 2001).

The Kenyan public procurement system has developed over the past five decades, from a system with no regulations in the 1960s to a system regulated by Treasury circulars between 1970 and 2000; and lastly, to a system firmly grounded on regulations at the turn of the $21^{\text {st }}$ Century (Embeli Iravo, Biraori \& Wamalwa, 2014; KACC \& PPOA, 2009; KIPPRA, 2006; Aketch, 2005). In the first decade of independence, public procurement was predominantly undertaken by external agencies due to inadequacy of supplies and competent suppliers in the local market. But as the economy expanded, procurement responsibilities were decentralised to ministries in 1974. Two studies commissioned by the government and the World Bank in 1986 and 1997, revealed that the public procurement system suffered from lack of: an effective legislative framework, a professional body to regulate activities of procurement officers, suppliers and service providers; and competent human resource, which made it vulnerable to irregularities and wastage of public resources in the range of KES 30 billion annually. Based on the findings, both studies emphasised the need for a comprehensive review and implementation of a reform process to minimise loss of public resources (KIPPRA, 2006; Basheka, 2006; Aketch, 2005; Odhiambo \& Kamau, 2003).

Procurement reforms were initiated in Kenya in 1999 with support from the World Bank, the International Monetary Fund (IMF), African Development Bank (ADB) and the International Trade Centre (ITC), among others. The reforms focused on delegation of authority, defining procurement thresholds, planning, and development of procurement manuals, among other components. Nonetheless, formulation of the Exchequer and Audit Regulations (Procurement Regulations) in 2001 remains the most crucial turning point of procurement reforms in Kenya (KIPPRA, 2006; Basheka, 2006; Aketch, 2005; Odhiambo \& Kamau, 2003).

Conspicuous components of reforms introduced by the Procurement Regulations of 2001 include the use standard tender documents, adherence to expenditure thresholds, upgrade of technical specifications to international standards, as well as equal treatment of all bidders irrespective of race, religion or nationality. Additional components of reforms propagated by the Procurement Regulations include advertisement of all tenders in the print media, transparency in opening tenders, reporting tender evaluation processes and outcomes, confidentiality of tender evaluation processes, as well as planning procurement activities in order to regulate emergency procurement, among others (Embeli et al., 2014; KACC \& PPOA, 2009; KIPPRA, 2006; Government of Kenya, 2001).

The Ministry of Education embarked on measures to entrench provisions of the Procurement Regulations in academic institutions in 2002 to improve efficiency of procurement practices; thus, enable schools to manage expenditure and utilise public resources judiciously (Embeli et al., 2014). In this regard, circulars were sent to all public secondary schools, directing them to follow the new regulations to improve procurement practices and procedures. The new measures included establishment of school tender committees, training members of such committees, as well as principals, deputy principals, and staff directly involved in procurement activities. In 2002, initial training workshops targeting principals and deputy principals of national and the then provincial schools were organised by the Directorate of Public Procurement (DPP), with support from the Treasury (Kavula et al., 2014).

Between 2002 and 2008, the public procurement landscape experienced various changes aimed at making public procurement more relevant and responsive to the needs of all sectors, as well as sustaining the reform agenda. For instance, in 2002, the Procurement Regulations were amended to incorporate changes necessitated by dynamics of procurement practices and to align with needs of various sub-sectors. In 2005, the the Public Procurement and Disposal Act (Procurement Act) was enacted to provide the requisite legal framework. In 2006, the Public Procurement and Disposal Regulations (Procurement Regulations) was revised further, and operated in 2007 through the Legal Notice No.174. In the same year, the Ministry of Education issued out the Public Procurement Manual for Schools and Colleges 2010 (Procurement Manual), which provides procurement guidelines on Kenya Education Sector Support Programme (KESSP) related expenditure (Embeli et al., 2014; Kavula et al., 2014; PPOA, 2010; KACC \& PPOA, 2009). The three instruments provide the primary legislative and policy frameworks for reforming procurement practices in public secondary schools.

The legislative and policy frameworks contain various provisions that are relevant to the theme of this study. For instance, Section 10 (1) of the Procurement Act, which requires all procuring entities to establish tender 
committees, in a manner that is set out in the Second Schedule. Tender committees are obligated to perform the functions listed under sub-section 2 (a) to (o), which include reviewing, verifying and ascertaining that all procurement and disposal activities are in line with provisions of the Act, Procurement Regulations, and tender documents (Government of Kenya, 2010; 2006). Within the context of public schools, Part 7 of the Second Schedule (the Procurement Regulations) requires school tender committees to have a membership of at least six heads of departments or members of the teaching staff, including the Matron or officer-in-charge of the boarding facilities, who are appointed by the Principal (Government of Kenya, 2006).

More still, Section 54 (1) of the Procurement Act provides opportunity for procuring entities to take such steps as are reasonable to bring the invitation to tender to the attention of those who may wish to submit their bids. This is particularly necessary where the estimated value of goods, services, or works equals or exceeds institutional expenditure threshold. Sub-section (2) provides that advertisements may be done through national newspapers, electronic media, and websites as well as in public and conspicuous places reserved for this purpose (Government of Kenya, 2010). Similarly, Guidelines for Potential Bidders identifies the media for advertising tender opportunities, including notice boards of government agencies, electronic media such as radio and television; newspapers and other print media (both local and international); individual public procuring entities' websites; and special websites for tender opportunities set by PPOA. The choice of advertisement media is determined by various factors, including tender value, technical expertise and level of capitation funding required; targeted market, whether local or international, as well as cost-efficiency of each advertising medium relative to others (PPOA, 2010).

Furthermore, Part IV, Section 36 of the Procurement Regulations provides that for purposes of section 71(c) of the Procurement Act, the minimum period between tender advertisement and deadline for submission of international tenders should be thirty days. The duration given to bidders to respond to tenders is a crucial indicator of transparency and commitment to obtain value for resources invested in tendering processes. The aim of tender advertising is to enhance transparency, accountability, efficiency, competitiveness, effectiveness, consistency, fairness, as well as responsiveness to aspirations, expectations and needs of target societies, in line with fundamental principles of sound procurement practices (OECD, 2009; World Bank, 2002; Thai, 2001).

Despite the existence of necessary legislative and policy frameworks, only a few studies have explored the extent to which public secondary schools across the country have implemented relevant provisions to reform their procurement practices. For instance, the Institute of Policy Analysis and Research [IPAR], (2007) revealed that more than half of secondary schools did not adhere to provisions of the legislative and policy frameworks in their tendering processes; resulting to multiple irregularities in the procurement of school equipment, learning materials, supplies, and hiring of staff. Kavula et al. (2014) identified lack of relevant procurement structures such as tender committees and sub-committees; lack of induction courses to enhance awareness and knowledge of Procurement Regulations; as well as lack of in-service training, as the key factors determining the success of procurement reforms in Kitui County. Similarly, Embeli et al. (2014) singled out lack of procurement skills, non-enforcement, negative organisational procurement culture and low knowledge of Procurement Regulations, as the main factors preventing procurement reforms in public secondary schools of Trans-Nzoia County. Lastly, Angokho, Juma \& Musienga (2014) reported that procurement reforms in public secondary schools of Vihiga County were influenced by general lack of information about the legislative and policy frameworks, principles, procedures and processes of procurement, among school tender committee members.

Notably though, none of the extant empirical literature is explicit about the relationship between various components of procurement reforms on expenditure management in public secondary schools. More specifically, there is a dearth of empirical literature regarding the influence of tender advertising on expenditure management in the schools, not only in Kenya but also in other developing countries. The study focused on various components of procurement reforms, however, this article narrows down to the aspect of tender advertising. Its purpose is to determine how public secondary schools complied with provisions on tender advertising, and how this influenced expenditure management. The idea was to determine whether compliance with provisions on tender advertising caused a reduction, an increase or no change in the level of procurement expenditure.

\section{Literature Review}

Public procurement reform is a subject that has elicited colossal interest among governments, civil society, multiand bi-lateral development institutions, as well as policy researchers all over the world. However, specific literature on how various components of procurement reforms influence expenditure management in public secondary schools remains scanty, in both developed and developing countries. This section explores extant literature on the said subject, with a view to identifying outcomes of procurement reforms on expenditure 
management in the education sector. In the United Kingdom (UK), public procurement is governed by the Public Contracts and Utilities Contracts Regulations of 2006, which implements European Union's procurement directives (Perry, 2011). Despite having a common legal framework, each member state of the UK has had its unique experiences with procurement reforms in the education sector. In Scotland, for instance, procurement reforms granted headteachers control of about $80 \%$ of school budget, and the ability to procure goods and services directly from suppliers (Scottish Parent-Teacher Council, 2011). Another key feature of procurement reforms in Scotland was the introduction of electronic procurement (e-procurement) system, where schools and suppliers meet online before engaging in procurement processes. In 2009, an evaluation process found that the reforms enhanced the capacity of procurement committees in public schools and led to greater efficiency, transparency and significant savings of public resources (Perry, 2011; Audit Scotland, 2009).

The Canadian public procurement system has gone through various reforms over the past four decades (Strobo \& Leschinsky, 2009). One aspect of reforms that significantly changed procurement practices in public schools is the introduction of e-procurement in 1990 (Swick \&Tétrault, 2014; Fagan, 2005). The transition to e-procurement was motivated by the need to: lower the cost of accessing vendors, advertising tenders and distributing bid documents; improve accessibility of public tender opportunities, improve competitiveness of quotations, as well as increase trade between vendors and public procuring entities, including school. About eight years later, more than $80 \%$ of public schools reported significant savings in their procurement budgets, as all tender procedures, including advertising, bid submission; evaluation and contracting were done online (Financial Management Institute \& Price Waterhouse Coopers, 2015; Fagan, 2005).

In Australia, public procurement reforms started in 1997 when the Financial Management and Accountability Act was enacted (Jones, 2014; Department of Treasury and Finance [DTF], 2012; DTF, 2006). Existing literature single out reforms that were initiated in the first decade of the $21^{\text {st }}$ Century, based on recommendations of a study conducted in 2003, which include institutional capacity strengthening and e-procurement. In 2012, the Schools Electronic Catalogue Ordering (SECO) system was implemented in all public schools in New South Wale (NSW). Two years later, up to 1,500 schools and 6,374 users were connected to the SECO system; and up to 128,389 purchase orders had been sent electronically to catalogued vendors. The SECO system improved expenditure management by enabling public schools to save up to AU\$218 million in two years (Jones, 2014).

The Indonesian public procurement reforms, which began in 2000, focused on establishing, training and supporting tender committees in public secondary schools, under guidelines provided by the National Public Procurement Office (NPPO) (Keppres, 2001). A progress report compiled in 2003, noted that decentralisation of the procurement system to public schools played a crucial role in improving efficiency by enabling the institutions to save up to Rupees 5 billion annually. However, school tender committees were ineffective because of inadequate budgets, which in turn, affected management of the procurement process (World Bank, 2003). In 2008, NPPO introduced e-procurement system as provided for in the procurement law, and all public institutions, including secondary schools were obligated to channel their procurement activities through the new system (Buehler, 2008). Even though the e-procurement was anticipated to produce positive results quickly, its effectiveness in the Indonesian public secondary context was hindered by inadequacy of functional computers, low internet penetration, inadequate training for school tender committees and resistance to change in some institutions (Buehler, 2008).

In Brazil, public procurement is primarily regulated by the Public Procurement Law and Section XXI, Article 37 of the Federal Constitution (Frizzo \& Oliveira, 2014; Kucharsky, 2009). Procurement reforms were initiated in 2001, with introduction of the e-procurement system - COMPRASNET, whose purpose was to eliminate corruption in public procurement. The system provides on-line procurement services, including price quoting and reverse auction commodity purchases (Kucharsky, 2009; Ozorio de Almeida, 2005). During the first two years of e-procurement, public secondary schools saved up to US $\$ 1.5 \mathrm{~m}$. By 2005 , more than half of public schools were registered in the e-procurement database. Even though the e-procurement increased the spectrum of suppliers, the reforms in schools was delayed by lack of necessary skills among school tender boards, as well as shortage of computers and low internet connectivity (Ozorio de Almeida, 2005).

Since independence, Ghana has attempted to address weaknesses in public procurement process through several financial laws, rules and policies (Adu-Fosu, 2016). The Public Procurement Act was enacted in 2003 to promote efficiency, transparency, and accountability in the procurement process (Anvuur, Kumaraswamy \& Male, 2006). As part of reforms, procurement law created the Public Procurement Board (PPB) with obligations such as policy and regulatory oversight, capacity building, addressing complaints, and promoting competition. The law also created tender committees in public institutions. In public secondary schools, tender committees are chaired by a member of school boards to control the influence of principals in tendering processes (Adu-Fosu, 2016; 
Anvuur, et al., 2006). A study conducted in 2005 revealed that public secondary schools were gradually complying with procurement reforms. However, non-compliance was penalised through reconstitution of school boards, transferring principals, terminating suspected contracts and arraigning suspects in courts of law (Anvuur et al., 2006). However, inadequate funding and unqualified procurement staff remain key factors undermining compliance and effect of procurement reforms on expenditure management (Adu-Fosu, 2016).

In Tanzania, public procurement reforms started in 2001 with enactment of the Public Procurement Act, which was amended in 2004 (Maliganya, 2015; Nkinga, 2003). The key changes introduced by the new procurement law included devolution of procurement operations to procuring entities, including public secondary schools (Maliganya, 2015). In 2004, Financial Management and Accounting Guidelines for Secondary Education Development Plan was developed in 2004 to guide procurement operations in public secondary schools (Ministry of Education \& Culture, 2005). Existing literature suggests that procurement reforms have yielded mixed results. For instance, the 2014/15 audit report revealed that procurement reforms had significantly reduced malpractices in public schools, which in turn, enabled the institutions to manage budgetary allocations more prudently than they did in previous years (Public Procurement Regulatory Authority [PPRA], 2014; Government of Tanzania, 2013). A study conducted by Lwitiko (2013) noted that even though public schools had complied with requirements of the Act, procurement operations in public schools were still marred by inefficiency, due to issues such as inadequate capacity among tender board members, as well as failure to advertise tender opportunities and to award tenders within original bid validity period due to incompetence.

Extant empirical literature reveals that challenge of procurement malpractices is universal; variation only exists in the level of manifestation and magnitude. Besides, whereas procurement systems of developed countries are advanced in terms of technology and operation efficiency, in developing nations, procurement systems are at nascent stages. Much of the on-going reforms in developed economies involve transformation from paper-based procurement to e-procurement.

Fiscal Decentralisation Theory holds that fiscal decentralisation is an indispensable process that forms part of public governance reforms. It entails the decentralisation of authority, responsibility, and accountability for the management of public revenues as well as expenditure to peripheral cost centres and communities. The theory further holds that decentralisation of expenditure management to peripheral cost centres and communities are inevitable within the framework of bottom-up approach to development planning. The ultimate goal is to achieve efficiency, effectiveness, equity, and democracy, which may be constrained by a centralised system. The theory assumes that decentralising expenditure management is likely to stimulate equitable distribution of national resources and spur regional economic growth by injecting public funds in peripheral economies (Rondinelli, 1981).

In education sector, decentralisation of expenditure management places authority, responsibility and accountability in the hands of school principals and management boards. The theory indicates that expenditure efficiency is likely to improve when communities surrounding cost centres are involved in partial financing, management and monitoring expenditure patterns (Winkler, 1989). By assessing the effects of procurement reforms on expenditure management, this study anchors on postulates of the Fiscal Decentralisation Theory. In Kenya, although the authority, responsibility, and accountability for expenditure management were decentralised to educational institutions in the 1970s, lack of a comprehensive legislative framework hampered expenditure efficiency, leading to wastage of public resources. The development of a legislative framework between 2001 initiated a national reforms process, aimed at improving procurement practices and restoring efficiency in expenditure management.

This study examined the influence of procurement reforms on expenditure management, which was operationalised as variation in per capita annual procurement expenditure assessed the efficiency of expenditure management in terms of variation in per capita procurement expenditure between the periods before reforms (1999-2002) and after reforms (2007-2010). The analysis controlled the effect of intervening variables such as student population, as well as type, category and location of schools to ensure validity in the relationship between components of procurement reforms (independent variables) and expenditure management (dependent variable). Figure 1 is a conceptual framework that summarises the hypothesised relationship between components of procurement reforms and expenditure management. 


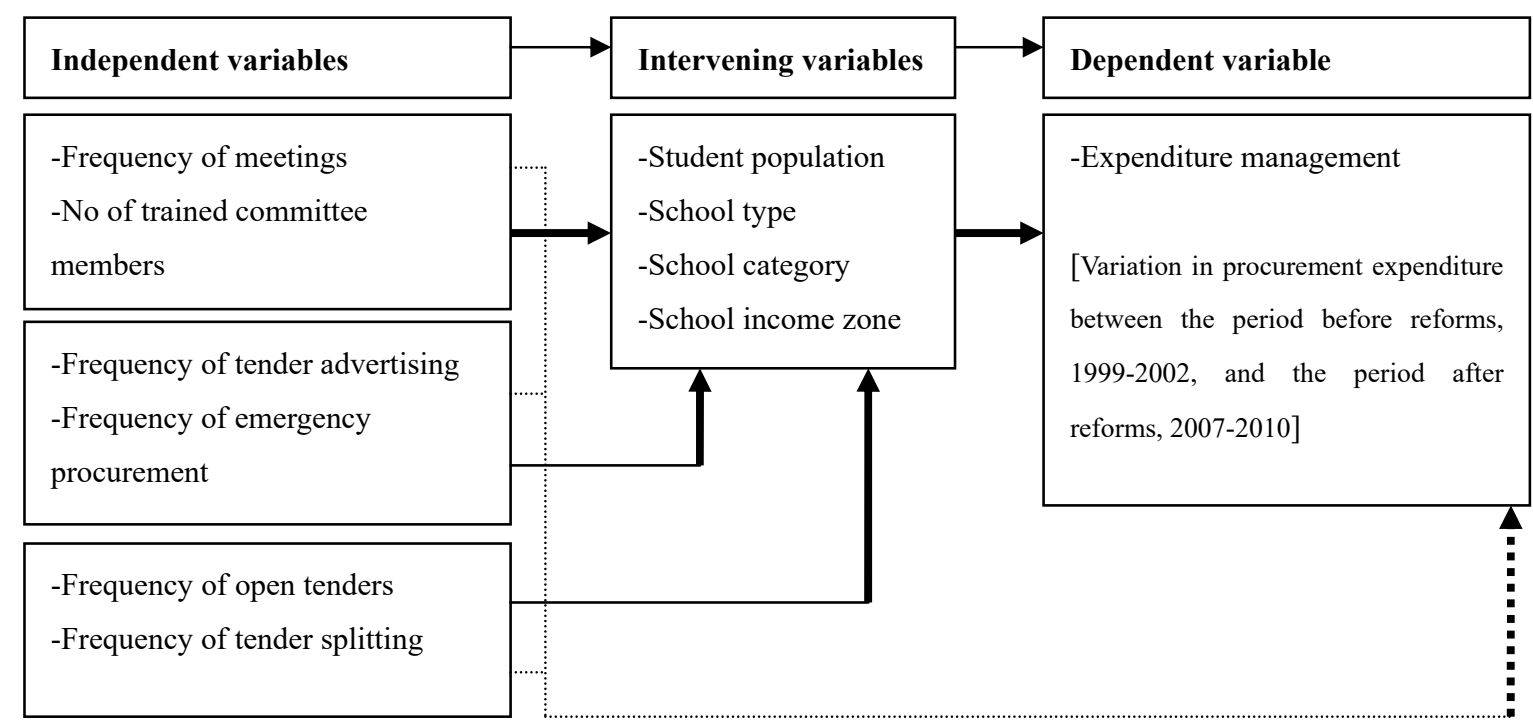

Figure 1. Relationship between components of procurement reforms \& expenditure management

\section{Methodology}

The evaluation research model III was applied to guide the research process. The model focuses on four dimensions of programme evaluation, including needs and problems (context analysis); resources and strategies needed to achieve objectives (input evaluation); analysis of the programme while it is operating (process evaluation), and the extent to which goals of a programme have been achieved (product evaluation) (Mugenda \& Mugenda, 2003). The study examined contextual issues such as challenges to procurement reforms in public secondary schools; input components such as number of tender committee members trained in procurement management; process evaluation, including the frequency of tender advertising; as well as product evaluation in terms of expenditure management.

The study targeted 78 public secondary schools in Nairobi City County. More specifically, the study focused on schools that had existed for at least 10 years prior to 2001 when procurement reforms in question were initiated. The criterion was based on the assumption that such schools had established databases for procurement expenditure and student population for the period under study, namely, 1999 to 2010. Within the schools, the study targeted deputy principals as well as members of Boards of Management (BOM) and Parents-Teachers' Association (PTA). Stratified random and purposive sampling procedures were applied to select schools and respondents. In this regard, the 76 public secondary schools were collectively designated as the population $\left(\mathrm{N}_{\mathrm{i}}\right)$ from where a sample $\left(\mathrm{n}_{\mathrm{i}}\right)$ was drawn, using Fisher's formula for sample size determination from finite populations (Gliner, Morgan \& Leech, 2009). The process yielded a sample size of 39 schools, are proportionately distribution, as indicated in Table 1.

Table 1. Distribution of sample size based on school category and gender

\begin{tabular}{lllll}
\hline Category of school & $\begin{array}{l}\text { Type } \\
\text { Boys, }\end{array}$ & Girls & Mixed & Sample \\
\hline A: National & 2 & 2 & 0 & 4 \\
B: County & 7 & 8 & 10 & 25 \\
C: Sub-County & 1 & 1 & 9 & 10 \\
Total & $\mathbf{1 0}$ & $\mathbf{1 0}$ & $\mathbf{1 9}$ & $\mathbf{3 9}$ \\
\hline
\end{tabular}

Deputy principals, as well as BOM and PTA members, were sampled purposively based on membership to school tender committees, as well as management, and/or oversight of school procurement activities. Primary data were sourced through self-administered questionnaires for deputy principals and key informant interviews for BOM and PTA members, while secondary data were sourced through a review of annual financial reports and student enrolment data, among others. Data collection instruments were pre-tested in six public secondary 
schools in Kiambu, Muranga and Nyeri Counties, which neighbour Nairobi County to the West and North. Primary data were sourced in May 2015. Even though the study targeted 39 schools, 35 questionnaires were filled at the end of data collection period, which suggests a response rate of $89.7 \%$.

Quantitative analysis techniques included frequency distributions with percentages; Analysis of variance (ANOVA), Chi-square $\left(\chi^{2}\right)$ statistic, Pearson's correlation coefficient and multiple regression (Gliner et al., 2009; Morgan, Leech, Gloeckner \& Barrett, 2007). Multiple regression modes were applied to determine the effect of each aspect of procurement reforms (independent variables) on expenditure management (dependent variable). In general form, the models are based on the premise that $Y$ is a function of a set of $k$ independent variables $\left(X_{1}\right.$, $X_{2} \ldots X_{k}$ ) in a population (Morgan et al., 2007). To express the model in an equation form, $X_{k j}$ denotes the value of the $j^{\text {th }}$ observation of variable $X_{k}$, as indicated:

$$
Y_{j}=\beta_{0}+\beta_{1} X_{1 j}+\beta_{2} X_{2 j}+\cdots \beta_{k} X_{k j}+\varepsilon_{j}
$$

Where: $\beta_{0}$ is the intercept; $\beta_{1} \ldots \beta_{k}$ are partial regression coefficients; $\varepsilon_{j}$ is the error term; $Y_{j}$ is the dependent variable; $X_{1} \ldots X_{k}$ are independent variables (Morgan et al., 2007; Bryman \& Cramer, 1998). In this study, the dependent variable $\left(Y_{j}\right)$ was variation in procurement expenditure, while the independent variables $\left(X_{1} \ldots X_{k}\right)$ included frequency of tender committee meetings in a quarter year, number of tender committee members trained in procurement management, frequency of tender advertisements, frequency of emergency procurement, frequency of applying open tender methods and frequency of tender splitting. The models generated three outputs of interest to this study, namely standardised regression coefficients (Beta weights), adjusted coefficient of determination $\left(\mathrm{R}^{2}\right)$ and $\mathrm{F}$ statistic.

The effect of independent variables was indicated by partial regression coefficients associated with each variable. Whereas a negative regression coefficient showed a negative effect, a positive coefficient indicted a positive effect on variation in procurement expenditure. The regression coefficients were standardised to generate Beta weights, to tell by how many standard deviation units the dependent variable was likely to change for a unit standard deviation change in an independent variable. The bigger the deviation from equilibrium, the stronger the effect of an independent variable (Morgan et al., 2007; Bryman \& Cramer, 1998). Goodness-of-fit shows how well a set of independent variables incorporated in regression models explain variation in the dependent variable, in this case, expenditure management. In multiple regression models, goodness-of-fit is explained by the coefficient of determination, designated as $\mathrm{R}^{2}$. Nevertheless, the adjusted $R^{2}$ provides a more accurate estimate of the explanatory power of a regression model than $R^{2}$ by considering the number of independent variables incorporated in the model. The significance of variation in $Y$ is indicated by the $F$ statistic (Morgan et al., 2007; Bryman \& Cramer, 1998). Furthermore, variation in $Y$ between the periods before reforms (1999-2002) and after reforms (2007-2010) was computed using the arithmetic formula, stating that:

$$
E_{v}=\left[\left(\frac{e_{1 a}+e_{2 a}+e_{3 a}+e_{4 a}}{p_{1 a}+p_{2 a}+p_{3 a}+p_{4 a}}\right) / n_{a}\right]-\left[\left(\frac{e_{1 b}+e_{2 b}+e_{3 b}+e_{4 b}}{p_{1 b}+p_{2 b}+p_{3 b}+p_{4 b}}\right) / n_{b}\right]
$$

Where $\boldsymbol{E}_{v}$ is the variation in procurement expenditure; $\boldsymbol{e}_{1 a} \ldots \boldsymbol{e}_{4 a}$ are procurement expenditures for years one to four after reforms; $\boldsymbol{e}_{1 b} \ldots \boldsymbol{e}_{4 b}$ are procurement expenditures for years one to four before reforms; $\boldsymbol{p}_{1 a} \ldots \boldsymbol{p}_{4 a}$ are the student populations for years one to four after reforms; $\boldsymbol{p}_{1 b} \ldots . . \boldsymbol{p}_{4 b}$ are the student populations for years one to four before reforms; $\boldsymbol{n}_{\boldsymbol{a}}$ is the number of years under focus after reforms and $\boldsymbol{n}_{\boldsymbol{b}}$ is the number of years under focus before reforms. The analysis was based on the assumption that the level of procurement expenditure was a function of student population; that schools procure goods, services, and works to meet the needs of students. As student population increases, the level of procurement expenditure is also expected to increase proportionately. Whereas a reduction in procurement expenditure between the two periods signified that the reforms were effective in improving fiscal discipline, an increase or no change indicated lack of effectiveness.

Qualitative data were transcribed and analysed using Nvivo 10 to identify emerging themes and patterns. Regarding ethical considerations, the investigator sought informed consent from potential respondents; and the process involved briefing them about the study, voluntary participation, withdrawal of consent and confidentiality of information sourced. Ethical clearance was obtained from the University of Nairobi Ethics and Research Committee. Regarding authorisation, a research permit was obtained from the National Commission for Science, Technology, and Innovation (NACOSTI), while an introduction letter was obtained from the University of Nairobi.

\section{Results}

The analysis revealed two outstanding patterns of variations in annual per capita procurement expenditure. Whereas the first pattern shows that procurement expenditure reduced consistently from the period before reforms, 
to the period during reforms and further down to the period after reforms; the second pattern indicates that procurement expenditure reduced from the period before reforms, to the period during reforms; but later increased during the period after reforms. On average, the Analysis of Variance (ANOVA) results, in Table 2, show that before reforms, the schools recorded an annual per capita procurement expenditure of KES 47,768, which declined to KES 34,625 during reforms and dropped further to KES 30,977 after reforms. In this regard, the analysis obtained a computed $\mathrm{F}_{(2,102)}$ statistic of 4.621 and a $\rho$-value of 0.012 , which suggests up to $95 \%$ chance that variations in annual per capita procurement expenditure were statistically significant, which in turn, suggests that procurement reforms may have significantly influenced the management of expenditure in public secondary schools.

Table 2. Variation in annual procurement expenditure - before, during and after reforms

\begin{tabular}{|c|c|c|c|c|c|c|c|c|}
\hline \multicolumn{9}{|c|}{ DESCRIPTIVES } \\
\hline \multirow{2}{*}{ Period } & \multirow{2}{*}{$\mathbf{N}$} & \multirow{2}{*}{ Mean } & \multirow{2}{*}{ SD } & \multirow{2}{*}{ SE } & \multicolumn{2}{|c|}{$95 \%$ CI for Mean } & \multirow{2}{*}{ Min } & \multirow{2}{*}{ Max } \\
\hline & & & & & $L B$ & $U B$ & & \\
\hline Before reforms & 35 & 47767.71 & 29854.40 & 5046.32 & 37512.37 & 58023.06 & 5175 & 117769 \\
\hline During reforms & 35 & 34625.29 & 21794.21 & 3683.89 & 27138.71 & 42111.86 & 4042 & 87489 \\
\hline After reforms & 35 & 30976.86 & 20152.47 & 3406.39 & 24054.24 & 37899.47 & 3863 & 87919 \\
\hline Total & 105 & 37789.95 & 25138.28 & 2453.25 & 32925.08 & 42654.83 & 3863 & 117769 \\
\hline \multicolumn{9}{|l|}{ ANOVA } \\
\hline & \multicolumn{2}{|c|}{ Sum of Squares } & df & \multicolumn{2}{|c|}{ Mean Square } & $\mathbf{F}$ & \multicolumn{2}{|l|}{ Sig. } \\
\hline Between groups & \multicolumn{2}{|c|}{5459619006.190} & 2 & \multicolumn{2}{|c|}{2729809503.095} & 4.621 & \multicolumn{2}{|l|}{$.012 * *$} \\
\hline Within groups & \multicolumn{2}{|c|}{60261437060.571} & 102 & \multicolumn{2}{|c|}{590798402.555} & & & \\
\hline Total & \multicolumn{2}{|c|}{65721056066.762} & 104 & & & & & \\
\hline
\end{tabular}

$*, * *, * * *$ show significance at $\rho<0.1, \rho<0.05$ and $\rho<0.01$ error margins, respectively.

The ANOVA results further show that annual per capita procurement expenditure reduced by circa $35 \%$ from KES 47,768 before reforms to KES 30,977 after reforms. Based on this, a computed $F_{(1,68)}$ statistic of 7.606 and a $\rho$-value of 0.007 were obtained, which suggests up to $99 \%$ chance that variation in per capita procurement expenditure between the two periods is statistically significant. Furthermore, the variation in annual per capita procurement expenditure between the periods before and after reforms were clustered into three categories of $<$ KES10,000, which was designated as 'small variation'; KES 10,000 to 19,999, designated as 'average variation'; and KES 20,000+, designated as 'big variation'. Whereas 'small variation' signifies a weak level of fiscal discipline, 'big variation' suggests a strong level of fiscal discipline. Based on this, the results show that of the 35 schools, $24(68.6 \%)$ recorded small variation in annual procurement expenditure, $7(20.0 \%)$ achieved average variation, while 4 (11.4\%) experienced big variation.

\subsection{Analysis of the Relationship between Background Profile and Expenditure Management}

The study captured various attributes of the schools including type, category, location, distribution by sub-counties, availability of tender committees and membership to such committees. The study further examined the relationship between such attributes and variation in procurement expenditure. The purpose of the analysis was to identify attributes that were likely to confound the relationship between the frequency of emergency procurement and expenditure management. The results in Table 3 show that among the schools that recorded small variation, 14 (58.3\%) were boarding, 7 (29.2\%) were day, while 3 (12.5\%) provided both day and boarding services. Among those that achieved big variation, $3(75.0 \%)$ were boarding schools, while $1(25.0 \%)$ was a day school. However, the analysis revealed no significant association between type of school and variation in annual procurement expenditure $\left(\chi^{2}=2.263\right.$, df $=4 \& \rho$-value $\left.=0.687\right)$. 
Table 3. Background attributes of the schools

\begin{tabular}{|c|c|c|c|c|c|c|c|c|}
\hline \multirow{2}{*}{ Attribute } & \multicolumn{2}{|c|}{ Small variation } & \multicolumn{2}{|c|}{ Average variation } & \multicolumn{2}{|c|}{ Big variation } & \multicolumn{2}{|l|}{ Total } \\
\hline & Frequency & $\%$ & Frequency & $\%$ & Frequency & $\%$ & Frequency & $\%$ \\
\hline \multicolumn{9}{|l|}{ Type } \\
\hline Boarding & 14 & 58.3 & 4 & 57.1 & 3 & 75.0 & 21 & 60.0 \\
\hline Day & 7 & 29.2 & 1 & 14.3 & 1 & 25.0 & 9 & 25.7 \\
\hline Day \& boarding & 3 & 12.5 & 2 & 28.6 & 0 & 0.0 & 5 & 14.3 \\
\hline Total & 24 & 100.0 & 7 & 100.0 & 4 & 100.0 & 35 & 100.0 \\
\hline \multicolumn{9}{|l|}{ Category } \\
\hline National & 1 & 4.2 & 2 & 28.5 & 0 & 0.0 & 3 & 8.6 \\
\hline County & 18 & 75.0 & 2 & 28.6 & 3 & 75.0 & 23 & 65.7 \\
\hline Sub-County & 5 & 20.8 & 3 & 42.9 & 1 & 25.0 & 9 & 25.7 \\
\hline Total & 24 & 100.0 & 7 & 100.0 & 4 & 100.0 & 35 & 100.0 \\
\hline \multicolumn{9}{|l|}{ Income zone } \\
\hline High-income zone & 7 & 29.2 & 2 & 28.6 & 1 & 25.0 & 10 & 28.6 \\
\hline Low-income zone & 17 & 70.8 & 5 & 71.4 & 3 & 75.0 & 25 & 71.4 \\
\hline Total & 24 & 100.0 & 7 & 100.0 & 4 & 100.0 & 35 & 100.0 \\
\hline \multicolumn{9}{|l|}{ Sub-County } \\
\hline Dagoretti & 4 & 16.7 & 1 & 14.3 & 2 & 50.0 & 7 & 20.0 \\
\hline Embakasi & 1 & 4.2 & 1 & 14.3 & 0 & 0.0 & 2 & 5.7 \\
\hline Kamukunji & 3 & 12.5 & 2 & 28.5 & 1 & 25.0 & 6 & 17.1 \\
\hline Kasarani & 3 & 12.5 & 0 & 0.0 & 0 & 0.0 & 3 & 8.7 \\
\hline Langata & 1 & 4.2 & 0 & 0.0 & 0 & 0.0 & 1 & 2.9 \\
\hline Makadara & 5 & 20.8 & 1 & 14.3 & 0 & 0.0 & 6 & 17.1 \\
\hline Starehe & 3 & 12.4 & 1 & 14.3 & 0 & 0.0 & 4 & 11.4 \\
\hline Westlands & 4 & 16.7 & 1 & 14.3 & 1 & 25.0 & 6 & 17.1 \\
\hline Total & 24 & 100.0 & 7 & 100.0 & 4 & 100.0 & 35 & 100.0 \\
\hline
\end{tabular}

Furthermore, the analysis revealed lack of a significant association between variation in annual procurement expenditure and: category of schools $\left(\chi^{2}=7.013, \mathrm{df}=4 \& \rho\right.$-value $\left.=0.135\right)$; location of schools $\left(\chi^{2}=0.029, \mathrm{df}=2\right.$ $\& \rho$-value $=0.986)$; as well as distribution of schools $\left(\chi^{2}=7.711, \mathrm{df}=14 \& \rho\right.$-value $\left.=0.904\right)$. In this regard, the results suggest that changes in annual procurement expenditure were homogenous across national, county and sub-county schools; as well as schools located in high and low income zones. In addition, all the sub-counties were homogenous in terms of such changes.

The results further show that all the 35 (100.0\%) schools had complied with the requirement of the Procurement Regulations by establishing tender committees to manage procurement and disposal activities. The membership of school tender committees ranged between 6 and 12. In this regard, the results in Table 4 show that mean membership of school tender committees was 8.96 for schools that recorded small variation in expenditure, 8.57 for those that experienced average variation and 8.50 for those with big variation. However, the analysis obtained a computed $F_{(2,32)}$ statistic of 0.326 and a $\rho$-value of 0.724 , which is not statistically significant; thus, suggesting lack of significant variation in membership of school tender committees for the three categories of schools. 
Table 4. Membership of school tender committees

\begin{tabular}{|c|c|c|c|c|c|c|c|c|}
\hline \multicolumn{9}{|l|}{ DESCRIPTIVES } \\
\hline \multirow{2}{*}{ Period } & \multirow{2}{*}{$\mathbf{N}$} & \multirow{2}{*}{ Mean } & \multirow{2}{*}{ SD } & \multirow{2}{*}{$\mathbf{S E}$} & \multicolumn{2}{|c|}{ 95\% CI for Mean } & \multirow{2}{*}{ Min } & \multirow{2}{*}{ Max } \\
\hline & & & & & $L B$ & $U B$ & & \\
\hline Small variation & 24 & 8.96 & 1.197 & 0.244 & 8.45 & 9.46 & 6 & 12 \\
\hline Average variation & 7 & 8.57 & 1.512 & 0.571 & 7.17 & 9.97 & 6 & 10 \\
\hline Big variation & 4 & 8.50 & 2.380 & 1.190 & 4.71 & 12.29 & 6 & 11 \\
\hline Total & 35 & 8.83 & 1.382 & 0.234 & 8.35 & 9.30 & 6 & 12 \\
\hline \multicolumn{9}{|l|}{ ANOVA } \\
\hline & Sum of Squares & df & Mean Square & & & $\mathbf{F}$ & Sig. & \\
\hline Between groups & 1.299 & 2 & 0.649 & & & 0.326 & 0.724 & \\
\hline Within groups & 63.673 & 32 & 1.990 & & & & & \\
\hline Total & 64.971 & 34 & & & & & & \\
\hline \multicolumn{9}{|l|}{ CORRELATIONS } \\
\hline & & & $\begin{array}{l}\text { Variation in } \\
\text { expenditure }\end{array}$ & procurement & Num & f tender & mittee & nbers \\
\hline \multirow{3}{*}{$\begin{array}{l}\text { Variation in procurement } \\
\text { expenditure }\end{array}$} & \multirow{2}{*}{\multicolumn{2}{|c|}{$\begin{array}{l}\text { Pearson Correlation } \\
\text { Sig. (2-tailed) }\end{array}$}} & \multicolumn{2}{|l|}{1} & & & \multicolumn{2}{|l|}{0.084} \\
\hline & & & & & & & \multicolumn{2}{|l|}{0.633} \\
\hline & \multicolumn{2}{|l|}{$\mathrm{N}$} & 35 & & & & \multicolumn{2}{|l|}{35} \\
\hline \multirow{3}{*}{$\begin{array}{l}\text { Number of tender } \\
\text { committee members }\end{array}$} & \multirow{2}{*}{\multicolumn{2}{|c|}{$\begin{array}{l}\text { Pearson Correlation } \\
\text { Sig. (2-tailed) }\end{array}$}} & 0.084 & & & & 1 & \\
\hline & & & 0.633 & & & & & \\
\hline & \multicolumn{2}{|c|}{$\mathrm{N}$} & 35 & & & & \multicolumn{2}{|l|}{35} \\
\hline
\end{tabular}

The results in Table 4 further suggest lack of a significant correlation between the membership of school tender committees and variation in annual procurement expenditure (Pearson Correlation Coefficient $[\mathrm{r}]=0.084$; $\rho$-value $=0.633$ ). In addition, key informant interviews revealed that school administration was represented in tender committees by deputy principals, who according to the Procurement Regulations are obligated to chair the committees. In some schools, county and sub-county education officers were co-opted in tender committees as ex-officio members; yet in others, a few BOM members sat in tender committees; which however, is contrary to provisions of the Procurement Regulations. The membership composition of school tender committees was further faulted for being skewed in favour of teaching staff. Even though non-teaching staff also constituted the committees, they lacked numerical strength to regulate decisions that go against institutional interests. Moreover, the involvement of teaching staff in procurement activities distracted them from undertaking their core business of tending to academic needs of their students.

\subsection{Bivariate Analysis of the Frequency of Emergency Procurement and Expenditure Management}

The results presented in Figure 2 show that of the 35 respondents, 21 (60.0\%) indicated that their schools had complied with requirements of Section 54 (1) of the Procurement Act, read together with the First Schedule of the Procurement Regulations, by advertising tenders 'always'. This included 10 (41.7\%) respondents whose schools experienced small variation in procurement expenditure, $7(100 \%)$ whose schools recorded average variation and $4(100.0 \%)$ whose schools reported big variation. In addition, $13(37.1 \%)$ respondents indicated that in their schools, tenders were advertised 'occasionally', while $1(2.9 \%)$ person hinted that tenders were 'never' advertised. Cumulatively, up to $14(40.0 \%)$ respondents hinted that their schools had not fully complied with provisions on tender advertising. 


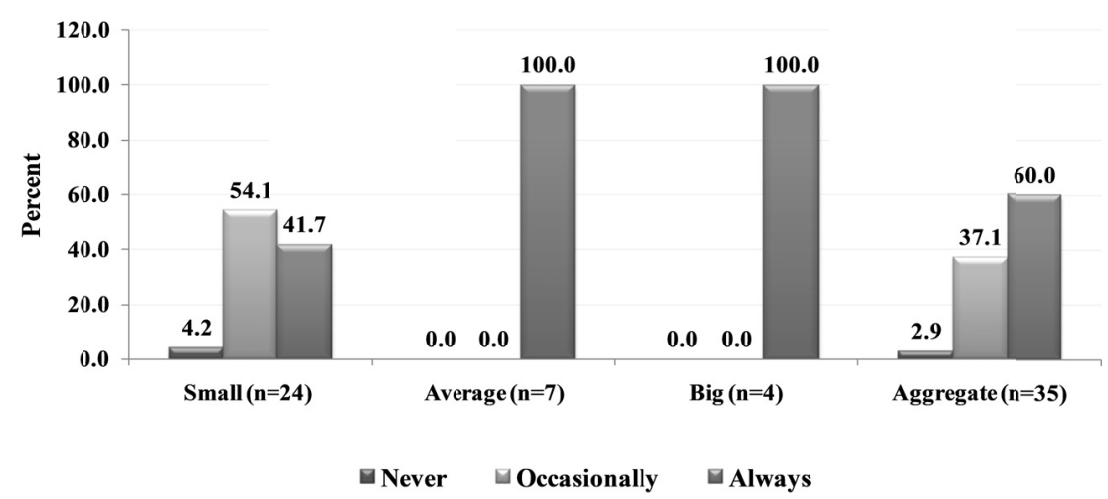

Figure 2. Frequency of tender advertising and variation in procurement expenditure

Based on the cross-tabulations, the analysis obtained a computed $\chi^{2}$ value of 10.694, with 4 degrees of freedom and a $\rho$-value of 0.030 , which is significant. The results suggest up to $95 \%$ chance that the frequency of tender advertising significantly associated with variation in procurement expenditure. Further analysis obtained a Pearson's Correlation Coefficient of -0.470 and a $\rho$-value of 0.004 , which suggests up to $99 \%$ chance that the frequency of tender advertising had a significant negative correlation. of fair strength, with variation in procurement expenditure. Better still, as the frequency of tender advertising increased due to procurement reforms, procurement expenditure tended to decrease. A reduction of procurement expenditure indicates improvement in fiscal discipline and expenditure management.

Key informants also revealed that most schools were consistent in advertising tenders using various channels, in line with Section 54 (2) of the Procurement Act and the First Schedule of the Procurement Regulations. Nonetheless, a few cases where tenders were awarded secretly were also cited. For instance, tenders such as repair of broken water and sewerage infrastructural facilities as well as construction projects funded by Constituency Development Funds (CDF), were often awarded secretly without proper advertisement as required by the legislative and policy frameworks. Participants linked such tenders with substandard goods and services, poor workmanship and inflated costs, which constrained effective management of procurement expenditure in public secondary schools.

Even though tender advertising is a crucial antecedent to expenditure management, key informants pointed out that the effectiveness of advertisements was impeded by lack of guidelines for schools to standardise the content, for instance, in terms of fees chargeable for tender documents and prequalification requirements. As a result, it was common to find two public schools in the same category posting adverts in completely different formats, setting different prequalification requirements for a similar project and charging differently for similar tender documents. Consequently, whereas some advertisements attracted many bidders, which helped defray advertising costs; others attracted too few bidders, below cost-recovery threshold. Standard guidelines for the designing tender adverts are likely to improve cost-recovery and reduce procurement expenditure.

The results presented in Table 5 show that 27 (79.4\%) respondents identified newspapers as the most common medium used by their schools to advertise tenders. This included $18(66.7 \%)$ respondents whose schools experienced small variation in procurement expenditure; $6(22.2 \%)$ whose schools recorded average variation and $3(11.1 \%)$ who indicated big variation. The second most common medium for advertising tenders was public notice boards, as stated by $14(41.2 \%)$ respondents, including $11(78.6 \%)$ whose schools recorded small variation in procurement expenditure and $3(21.4 \%)$ whose schools experienced average variation. 
Table 5. Types of advertising media commonly used by school tender committees

\begin{tabular}{|c|c|c|c|c|c|c|c|c|c|}
\hline \multirow{3}{*}{$\begin{array}{l}\text { Commonly } \\
\text { used media }\end{array}$} & \multirow{3}{*}{$\mathbf{F q}$} & \multirow{3}{*}{$\begin{array}{l}\% \text { of total } \\
\text { frequency }\end{array}$} & \multirow{3}{*}{$\%$ of sample size (n) } & \multicolumn{6}{|c|}{ Variation in procurement expenditure } \\
\hline & & & & \multicolumn{2}{|c|}{ Small } & \multicolumn{2}{|c|}{ Average } & \multicolumn{2}{|c|}{ Big } \\
\hline & & & & $F q$ & $\%$ & $F q$ & $\%$ & $F q$ & $\%$ \\
\hline Newspapers & 27 & 47.4 & 79.4 & 18 & 66.7 & 6 & 22.2 & 3 & 11.1 \\
\hline Public notice boards & 14 & 24.6 & 41.2 & 11 & 78.6 & 3 & 21.4 & 0 & 0.0 \\
\hline School notice boards & 7 & 12.3 & 20.6 & 7 & 100.0 & 0 & 0.0 & 0 & 0.0 \\
\hline Public/social forums & 5 & 8.8 & 14.7 & 1 & 20.0 & 3 & 60.0 & 1 & 20.0 \\
\hline School website & 4 & 7.0 & 11.8 & 1 & 25.0 & 2 & 50.0 & 1 & 25.0 \\
\hline Total frequency & 57 & 100.0 & 167.6 & 38 & 66.7 & 14 & 24.6 & 5 & 8.8 \\
\hline Sample size (n) & 34 & & & & & & & & \\
\hline
\end{tabular}

NB: Multiple response variable; hence, total frequency ( $f q)$ exceeds sample size (n).

In addition, school notice boards were mentioned by 7 (20.6\%) respondents, all of whose schools recorded small variation in procurement expenditure; while $5(14.7 \%)$ respondents cited public and/or social forums such as government functions and religious events. This group included $3(60.0 \%)$ respondents whose schools experienced average variation in procurement expenditure. Similar findings were revealed by key informants who cited school notice boards, social forums such as churches, public notice boards, and newspapers. The type of media used depends on factors such as tender value and type, as well as level of expertise and quality specifications required. Notably though, more than three-quarters of schools had complied with legal provisions requiring all procuring entities to advertise tender opportunities. Participants noted that this was a positive step towards effective management of procurement expenditure.

\subsection{Multivariate Analysis of the Frequency of Emergency Procurement and Expenditure Management}

The independent variables incorporated in this study included frequency of tender committee meetings in a quarter year, number of tender committee members trained on procurement management, frequency of tender advertising, frequency of emergency procurement, frequency of open tenders and frequency of tender splitting. The analysis generated two regression models. The first model incorporated independent variables only, while the second model incorporated both independent and intervening variables, including student population, school type, school category and income zone.

The models generated three important outputs, including standardised regression coefficients (beta weights), adjusted coefficient of determination $\left(\mathrm{R}^{2}\right)$ and the significance of $\mathrm{F}$ statistic. Beta weights showed the effect of each aspect of procurement reforms on expenditure management in terms of direction (either positive or negative) as well as in terms of relative importance. Whereas a negative beta weight suggests a reduction in procurement expenditure, a positive beta weight indicates an increment in the same. In this study, reduction or increment in procurement expenditure was considered a crucial indicator of how good or bad procurement reforms had influenced the performance of public secondary schools in terms of expenditure management. More still, the adjusted $\mathrm{R}^{2}$ shows how well the components of procurement reforms explained variation in expenditure; while the significance of $\mathrm{F}$ statistic indicates whether the effect of procurement reforms on expenditure management made statistical sense or not.

The results of multivariate analysis are summarised in Table 6; and they show beta weights, as well as related t-statistic and $\rho$-values (Sig.) for each aspect of procurement reforms. However, this article discusses the frequency of tender advertising, being the aspect that influenced the biggest reduction in procurement expenditure. In this regard, the aspect obtained a beta weight of $-0.300(\mathrm{t}$-statistic $=-2.429 \& \rho$-value $=0.022)$ in the first model. In model 2 , the beta weight decreased to $-0.335(\mathrm{t}$-statistic $=-2.629 \& \rho$-value $=0.014)$. The results in both models suggest up to $95 \%$ chance that the frequency of tender advertising caused a significant reduction in procurement expenditure, which indicates an improvement (positive effect) in fiscal discipline and expenditure management. Consequently, the null hypothesis, which stated that the frequency of tender advertisements has a negative effect on expenditure management in public secondary schools, was rejected for being untrue. Key informants observed that advertising tenders widened the scope of choices, which in turn, enabled school tender committees to select most qualified bidders, based on technical capacity, financial capability, and competitiveness of prices. This enabled tender committees to reduce expenditure by awarding tenders to bidders with lowest prices and best technical capacity, which also enabled schools to obtain value for money. 
Table 6. Components of procurement reforms influencing expenditure management

\begin{tabular}{|c|c|c|c|c|c|c|}
\hline Independent variables & $\begin{array}{l}\text { MODEL 1 } \\
\text { Standardised } \\
\text { coefficients } \\
\text { (Beta) }\end{array}$ & $t$ & Sig. & $\begin{array}{l}\text { MODEL } 2 \\
\text { Standardised } \\
\text { coefficients } \\
\text { (Beta) }\end{array}$ & $t$ & Sig. \\
\hline $\begin{array}{l}\text { No. of members with training on } \\
\text { procurement management }\end{array}$ & -0.063 & -1.468 & $0.084 *$ & -0.060 & -1.406 & $0.088^{*}$ \\
\hline Frequency of open tenders & -0.146 & -1.161 & 0.255 & -0.068 & -0.485 & 0.632 \\
\hline $\begin{array}{lll}\text { Frequency } & \text { of } & \text { tender } \\
\text { advertising } & & \end{array}$ & -0.300 & -2.429 & $0.022 * *$ & -0.335 & -2.639 & $0.014 * *$ \\
\hline Number of quarterly meetings & -0.138 & -1.100 & 0.281 & -0.021 & -0.153 & 0.880 \\
\hline $\begin{array}{l}\text { Frequency of emergency } \\
\text { procurement }\end{array}$ & 0.352 & 2.596 & $0.015 * *$ & 0.457 & 3.240 & $0.003 * * *$ \\
\hline Frequency of tender splitting & 0.357 & 2.517 & $0.018 * *$ & 0.406 & 2.645 & $0.014 * *$ \\
\hline
\end{tabular}

$*, * *, * * *$ show significance at $\rho<0.1, \rho<0.05$ and $\rho<0.01$ error margins, respectively.

Furthermore, tenders were advertised using various media, including newspapers, notice boards, as well as social forums, which varied significantly in terms of cost, which in turn, influenced procurement expenditure. Whereas some methods required the engagement of communication agencies, others were executed by members of school tender committees themselves, sometimes assisted by support staff and community leaders, at no cost. Tender committees chose the method(s) to apply in each procurement activity, based on parameters such as tender value, desired level of technical expertise, desired amount of capitation funding and cost, among other factors. Nonetheless, application of methods with minimal or no cost implications such as notice boards and social forums, may have contributed more to the reduction of procurement expenditure. Ideally, the cost of planning, designing, and communicating tender advertis should be recovered through non-refundable application fees; however, this depends on the design of such advertisements. Full cost recovery is possible where advertisements are designed using appealing language, reasonable minimum qualifications, and appropriateness of timing. Successful recovery of costs incurred when advertising tenders is also a crucial factor that contributed to the reduction of procurement expenditure.

Relative importance of independent variables in terms of effects caused on a dependent variable is indicated by the magnitude of beta weights. Whereas a negative (-) sign before a beta weight shows a decrement effect on the dependent variable, a positive $(+)$ sign suggests an increment effect. The effect of independent variables is nil at 0.0 , but increases away from 0.0 in both directions $( \pm)$. The bigger the deviation from the equilibrium, the stronger the effect associated with a particular independent variable. Based on this principle, the analysis showed that among the components that caused a reduction in procurement expenditure, the frequency of tender advertising as the most important (beta weight $=-0.355)$; followed by the frequency of open tenders (beta weight $=-0.068$ ); number of members with training in procurement management (beta weight $=-0.060$ ) and average number of tender committee meetings per quarter year (beta weight $=-0.021)$.

The results further show that model 1 generated an adjusted $\mathrm{R}^{2}$ of 0.537 , which suggest that the components of procurement reforms analysed by the study accounted for up to $53.7 \%$ variation of procurement expenditure over the reference period. When intervening variables were added into the model, the adjusted $\mathrm{R}^{2}$ increased to 0.563 , which suggest that model 2 accounted for $56.3 \%$ of variation in procurement expenditure. The results also suggest that both models had a moderate strength in estimating the effect of procurement reforms on expenditure management. Besides, the strength of both models was statistically significant at $99 \%$ confidence level ( $\rho$-value $<0.000)$.

\section{Discussions and Conclusions}

The study aimed at establishing the extent to which public secondary schools in Nairobi City County had complied with legislative and policy provisions guiding public procurement reforms in Kenya, as well as the effect of selected components of reforms on expenditure management. This article focuses on the frequency of tender advertising, being the aspect that caused the biggest reduction in procurement expenditure. Management of public procurement expenditure is a fundamental element of sustainable delivery of quality services to citizens; and its purpose is to achieve three interconnected objectives, including improving fiscal discipline, optimising allocation of resources in line with budgetary policy priorities, and ensuring good operational management. Improving fiscal discipline involves controlling the amount of fiscal resources spent in the procurement of goods, 
services, and works, with a view to minimising loss through accidental wastage and/or afore-thought malpractices.

The findings show that up to two-thirds of the schools $(21,60.0 \%)$ were consistently advertising tenders using various media such as set out by Section 54 (1) and (2) of the Procurement Act and the First Schedule of the Procurement Regulations, which in turn, influenced a reduction in procurement expenditure between the periods before reforms (1999-2002) and after reforms (2007-2010). In this regard, the findings reveal up to $95 \%$ chance that the frequency of tender advertising had a significant and negative correlation, of fair strength, with variation in procurement expenditure $(r=-0.470 \& \rho$-value $=0.004)$. Furthermore, the aspect caused a significant reduction in procurement expenditure (beta weight $=-0.335$, t-statistic $=-2.639 \& \rho$-value $=0.014)$, which indicates an improvement (positive effect) in fiscal discipline and expenditure management.

Advertising tenders caused a positive effect by widening the scope of choices for school tender committees, which enabled selection of most qualified bidders, based on technical capacity, financial capability, and competitiveness of quotations. In this regard, schools advertising their tenders always were likely to be more efficient in expenditure management than those that advertised tenders inconsistently or did not advertise at all. In view of this, ensuring consistency in advertising tenders is likely to help many public secondary schools to get value for money by choosing the most capable suppliers offering most competent quality-cost combination. Again, advertising tenders ensures that procurement procedures embrace the basic principles of sound procurement practice, which include transparency, accountability, efficiency, competitiveness, as well as fair dealing and value for money (OECD, 2009; World Bank, 2002; Thai, 2001). When procuring entities acquire quality goods, services and works at the most competitive price, they are not only able to deliver quality services consistently, but also and more importantly, are able to prevent wastage of public resources. Consequently, tender advertising enhances the effectiveness and contribution of public procurement in national socio-economic development.

The media through which tenders are advertised is of great importance to procuring entities, particularly in terms of cost implications. In this study, the findings hinted that advertisement of tenders can become a significant cause for increment in procurement expenditure. Hence, tender committees should choose appropriate media for advertising tenders, based on factors such as tender value, desired level of technical expertise, and amount of capitation funding, among others. Even where costly media such as newspapers are used, care should be taken to ensure full cost recovery, which may be achieved by planning, designing, and communicating adverts in the most attractive way possible. Even though full cost recovery is possible where adverts attract huge response from bidders, the process may be complicated by lack of standard guidelines for designing and standardising tender adverts in public secondary schools. Thus, developing and disseminating such guidelines is likely to make tender advertisements more attractive to bidders and thus, self-financing; thereby, reduce procurement expenditure.

In view of the above, the Ministry of Education and Directorate of Public Procurement (DPP) should invest in sensitising school tender committees regarding the need to advertise all tenders using most cost-effective media, as demanded by Section 54 (1) and (2) of the Procurement Act, and guided by the First Schedule of the Procurement Regulations. Advertising tenders consistently is likely to help many public secondary schools to obtain value for money by avoiding substandard goods and services, as well as poor workmanship and inflated costs. Again, the Ministry and the DPP should develop guidelines for designing tender advertisements in order to make them more attractive to bidders and thus, make tender advertising self-financing through cost-recovery. This will go a long way in reducing procurement expenditure.

\section{References}

Adu-Fosu, B. (2016). Compliance with public procurement act and its correlation with procurement performance of senior high schools in Ghana. European Journal of Business and Management, 8(11), 96-101.

Aketch J.M. (2005). Development partners and governance of public procurement in Kenya: Enhancing democracy in the administration of aid. New York: Institute of International Justice, New York University School of Law.

Angokho, A.C., Juma, S. \& Musienga, D. (2014). Challenges in achieving transparency and accountability in public procurement procedures in secondary schools in Sabatia Sub-County, Vihiga County, Kenya. International Journal of Innovative Research \& Development, 3(5), 324-330.

Anvuur, A., Kumaraswamy, M. \& Male, S. (2006). Taking forward public procurement reforms in Ghana. Paper presented during the International Symposium on Construction in Developing Economies, held from $18^{\text {th }}$ to $20^{\text {th }}$, January 2006, in Santiago Chile. 
Audit Scotland (2009). Improving public sector purchasing. Edinburgh: Audit Scotland.

Basheka, B. (2006). Derivations from applicable procurement and disposals method. Procurement News, 2(3), 44-45.

Bryman, A., \& Cramer, D. (1997). Quantitative Data Analysis with SPSS for Windows: a guide for social scientists. London: Routledge.

Buehler, M. (2008). Public procurement reform in Indonesian provinces and sub-districts: The historical institutional context and lessons learned from analytical work. Washington, DC: World Bank.

Department of Treasury \& Finance [DTF] (2006). Public procurement reforms in West Australia. Canberra: DTF.

Department of Treasury \& Finance [DTF] (2012). Procurement reforms in West Australia. Canberra: DTF.

Embeli, S. J, Iravo, M. A., Biraori, O. E., \& Wamalwa, W. R. (2014). Factors affecting the use of Public Procurement and Disposal Act of 2005 in public secondary schools - a survey study of Trans-Nzoia County in Kenya. International Journal of Recent Research in Commerce Economics and Management, 1(3), 29-38.

Fagan, J. (2005). Transparency through electronic procurement: Canada's approach. Ottawa: Inter-American Development Bank.

Financial Management Institute [FMI] \& Price Waterhouse Coopers [PWC] (2015). Procurement: Who does it well? Paper presented at the Annual International Supply Management Conference, held on $26^{\text {th }}$ February, 2015, in Edmonton Alberta.

Frizzo, H. \& Oliveira, P. (2014). Public procurement in Brazil: Overview. Rio-de-Janeiro: Trench, Rossi e Watanabe Advogados.

Gliner, J. G., Morgan, G. A. \& Leech, N. L. (2009). Research methods in applied settings: An integrated approach to design and analysis $\left(2^{\text {nd }}\right.$ ed.). New York: Routledge.

Government of Kenya (2001). The exchequer and audit (public procurement) regulations, 2001. Nairobi: Ministry of Finance.

Government of Kenya (2006). The public procurement and disposal regulations, 2006. Nairobi: National Council for Law Reporting.

Government of Kenya (2010). The public procurement and disposal act: Chapter 412C. Nairobi: National Council for Law Reporting.

Government of Tanzania (2013). Annual general report of the controller and auditor general. Dar-es-Salaam: National Audit Office of Tanzania.

Institute of Policy Analysis \& Research [IPAR] (2007). Making public secondary education affordable. Occasional publication issue 3. Nairobi: IPAR.

Jones, D. (2014). NSW Government: Procurement case studies. Sydney: NSW Government.

Kavula, J., Kalai, J.M. \& Migosi, J. (2014). Determinants of implementation of public procurement regulations in Kenya. International Journal of Educational Research and Reviews, 2(1), 9-16.

Kenya Anti-Corruption Commission [KACC] \& Public Procurement Oversight Authority [PPOA] (2009). Corruption prevention guidelines in public procurement. Nairobi: KACC \& PPOA.

Kenya Institute of Public Policy Research \& Analysis [KIPPRA] (2006). Public procurement policy in Kenya: The need for a coherent policy framework. Policy Brief, No. 3/2006.

Kucharsky, J. (2009). Procurement in Brazil: Electronic procurement as anti-corruption reform. The International Journal of Policy Solutions, 10, 1-14.

Maliganya, C. E. (2015). The next age of public procurement reforms in Tanzania: looking for the best value for money. Washington, DC: The George Washington University.

Ministry of Education \& Culture (2005). Revised financial management and accounting guidelines for the secondary education development plan. 2004-2009. Dar-es-Salaam: Education Sector Development Programme.

Morgan, G. A., Leech, N. L., Gloeckner, G. W., \& Barrett, K.C. (2011). IBM SPSS for introductory statistics: Use and interpretation (4th ed.). New York: Routledge. 
Mugenda, O. M., \& Mugenda, A. G. (2003): Research methods: Quantitative and qualitative approaches. Nairobi: ACTS Press.

Nkinga N. S. D. (2003). Public procurement reform- the Tanzanian experience. Paper presented at the joint WTO-World Bank regional workshop on procurement reforms and public procurement for the English-speaking African Countries, held from 14 to $17^{\text {th }}$ January, 2003, in Dar-Es Salaam, Tanzania.

Odhiambo, W. \& Kamau, P. (2003). Public procurement: Lessons from Kenya, Tanzania and Uganda: Working paper No. 208. Paris: OECD Development Centre.

Organisation for Economic Cooperation \& Development [OECD] (2001). Strengthening partner country procurement capacities: A needs assessment. Paris: Crown Agents.

Organisation for Economic Cooperation \& Development [OECD] (2009). Principles for Integrity in Public Procurement. Paris: OECD.

Ozorio de Almeida, M. (2005), E-procurement by Brazilian federal government. Retrieved from http://www.comprasnet.gov.br

Perry, C. (2011). Procurement in education in other jurisdictions: Research Paper, No. 118/11. Dublin: Research and Information Service, Northern Ireland Assembly.

Public Procurement Oversight Authority [PPOA] (2010). Public procurement manual for schools andcolleges. Nairobi: PPOA.

Public Procurement Regulatory Authority [PPRA] (2014). Tanzania Procurement Journal, 7(13).

Rondinelli, D. A. (1981). Government decentralisation in comparative theory and practice in developing countries. International Review of Administrative Science, 47(2), 133-147. https://doi.org/10.1177/002085238004700205

Scottish Parent-Teacher Council [SPTC] (2011). A simple outline of devolved school management. Edinburgh: SPTC.

Strobo, G., \& Leschinsky, D. (2009). The Canadian public procurement regime. In R. H. García (Ed.), International public procurement: A guide to best practice. London: Globe Law and Business Publishing.

Swick, B. C., \& Tétrault, M. (2014). Public procurement in Canada: Overview. London: Thomson Reuters.

Thai, K. V. (2001). Public procurement re-examined. Journal of Public Procurement, 1(1), 9-50.

Winkler, D. (1989). Decentralisation in education: An economic perspective. Washington, DC: World Bank.

World Bank. (2002). Revised country procurement assessment report procedures. Washington, DC: World Bank. https://doi.org/10.1596/13885

World Bank. (2003). Country procurement assessment report, Ghana. Washington, DC: World Bank. https://doi.org/10.1596/14344

\section{Copyrights}

Copyright for this article is retained by the author(s), with first publication rights granted to the journal.

This is an open-access article distributed under the terms and conditions of the Creative Commons Attribution license (http://creativecommons.org/licenses/by/4.0/). 